\title{
The Toxic Effects of Crude Oil in Some Freshwater Cyanobacteria
}

\author{
Abdul Hameed M. Jawad Al Obaidy, Muwafaq H. M. Lami \\ Environmental Research Center, University of Technology, Baghdad, Iraq \\ Email: jawaddhy@yahoo.co.in, alshemeri@yahoo.com
}

Received 18 January 2014; revised 15 February 2014; accepted 12 March 2014

Copyright (C) 2014 by authors and Scientific Research Publishing Inc.

This work is licensed under the Creative Commons Attribution International License (CC BY).

http://creativecommons.org/licenses/by/4.0/

(c) (i) Open Access

\begin{abstract}
Toxicity effect of the Iraqi crude oil on the growth of two Cyanobacteria strains Microcystis flos-aquae (Wittr.) Kircher (unicellular) and Nostoc carneum Agardh (filamentous) was studied basing on it is biomass expressed as chlorophyll-a $(\mu \mathrm{g} / \mathrm{ml})$. Growth rate and doubling time of the cells were also calculated accordingly in present or absent of the crude oil. Also, Microscopical examination was observed to detect the morphological changes. Both species appeared different responses towards oil toxic influences with different concentrations and time of exposure. Growth was decreased gradually with Microcystis with addition of 10, 30, 50 and $70 \mathrm{mg} / \mathrm{l}$ of the crude oil, slightly toxic effects were observed with Nostoc in comparison to the control. Different significant correlations $(P \leq 0.05)$ were observed between growth of the cyanobacteria and the oil concentrations. Furthermore, results demonstrated that Microcystis was considered to be more sensitive than Nostoc towards crude oil concentrations.
\end{abstract}

\section{Keywords}

Toxicity, Crude Oil, Cyanobacteria, Batch Culture, Bioassay, Biomonitoring

\section{Introduction}

Petroleum is a major anthropogenic contaminant in the aquatic environment and may affect the community composition of the phytoplankton [1]. At today's world, consumption level of about 85 million barrels per day of crude oil [2] which has certainly been accompanied by growing incidence of pollution due to oil spillage. The annual influx of petroleum into the marine environment is estimated to be between $1.1-7.2$ million metric tons [3]. In addition, it was estimated that $28 \%$ - $30 \%$ of spilled oil enters freshwater environment [4]. Oil pollution may be derived from various sources, Oil refinery wastes release high levels of hydrocarbons to water, over and 
above these, natural seepage from ground and industrial activities other than petro-chemistry are also considered sources of dangerous pollutants [5]-[7].

The adverse effects of petroleum pollution on such integral component of aquatic ecosystems may be of great significance. Since the toxicity of oil to biota is caused by unsaturated hydrocarbons, naphthenic acids and another compound containing aromatic groups and nitrogen [8], the actual toxic effects dose is closely related to the amount of dissolved non-volatile material [9]. The inhibition effects of petroleum hydrocarbons on microorganisms, including cyanobacteria, have been studied to address the problem of oil pollution [10]-[13]. However, the conclusion that many investigators have reached is that petroleum hydrocarbons influence microalgal biomass either negatively or positively [14]. In this connection, there is growing evidence of direct microalgal/cyanobacteria consumption of crude oil, but mainly by providing oxygen, and in the case of Cyanobacteria, fixed nitrogen [15] [16]. It is demonstrated that bacterial growth on adsorbed polycyclic aromatic hydrocarbons can result in a linear increase in biomass concentration. Furthermore, the rate of metabolism which can take place sometimes exceeds the rate of mass transfer from the environment to the cell, which leads not only to limitation of growth rate but also to absence of a toxic effect by these hydrocarbons [17].

A possible explanation for the latter is that the mass transfer of molecules to the cells is limited by the small surface area of the solid particles [18], and the Solid hydrocarbon becomes toxic only after long periods of incubation [19].

Crude oil contamination has caused critical concerns in environment [20]. In the same framework, in Iraq, with recently accelerating oil projects investments, which are often responsible for causing oil pollution accidents, a little investigation had been attempt to realizing the hazardous influences with respect to oil pollution on the freshwater ecosystems. Thus, the overall objective of this study was to evaluate the toxicity of the crude oil on growth of tow Cyanobacteria species Microcystis flos-aquae and Nostoc carneum, with special emphasis for their role in oil bio-indication and bio-monitoring.

\section{Materials and Methods}

\subsection{Cyanobacteria and Culture Conditions}

Axenic cultures of Cyanobacteria Microcystis flos-aquae (Wittr.) Kircher (Chroococcales) and Nostoc carneum Agardh (Nostocales) were isolated from Tigris River (Baghdad-Iraq), and conducted with all experiments. Chuno. 10 culture medium was used as specific growing culture of which components were illustrated by Chu [21]. Both strains were grown at $25^{\circ} \mathrm{C}$ and \pm 2500 Lux as optimum physical growth conditions were provided by white fluorescent lamps under light/dark regime of 18/6 hours for the duration of the experiments. Optimal phytonutrient concentrations (10 mg/L nitrate, $5 \mathrm{mg} / \mathrm{L}$ phosphate and 1:10 mg/L N:P ratio) as optimal chemical conditions were used in order to obtain higher growth rates and lower doubling time of cells. The phosphate-buffered medium was finally adjusted to $\mathrm{pH} 7$ with $\mathrm{NaOH}$. The medium for preculture was autoclaved in $1000 \mathrm{ml}$ polycarbonate flasks. Patterson's method was used to purify the culture to get an axenic culture [22]. The stock cultures were continuously recultivated and introduced to the experimental systems at logarithmic phase. Triplicate cultures were run for each treatment.

\subsection{Crude Oil}

Iraqi medium crude oil (Basrah type), supplied by Al-Dura oil refinery was used in the present work (Table 1). Oil-in-water emulsions were prepared by mechanical shaking (3 min. at 1000 vibration/min.) of a McCartney vial containing $10 \mathrm{ml}$ of sterile deionized water and crude oil [23]. Different concentrations of the emulsified oil were added to the algae established an actual concentrations of (10, 30, 50 and $75 \mathrm{mg} / \mathrm{l})$ during the exponential phase of growth. For control, algae were just incubated in culture medium.

\subsection{Measurement of Growth}

Chlorophyll-a content used as an indicator for algal growth, was measured daily as long as exposure period using the following formula proposed by Vollenweider [24].

$$
\text { Chlorophyll-a }\left(\mu \mathrm{g} \cdot \mathrm{ml}^{-1}\right)=11.9 \times 2.43\left(\mathrm{D}_{\mathrm{b}}-\mathrm{D}_{\mathrm{a}}\right) \times(\mathrm{V} / \mathrm{L})
$$

where: 
Table 1. Physical characterization of Iraqi crude oil-Basrah type.

\begin{tabular}{cc}
\hline Characteristics & values \\
\hline A.P.I Gravity at observed temp. & 32.1 \\
Temp. ${ }^{\circ} \mathrm{F}$ & 57 \\
Temp. at $60{ }^{\circ} \mathrm{F}$ & 32.2 \\
Density at observed temp. & 0.8620 \\
Temp. ${ }^{\circ} \mathrm{C}$ & 14.50 \\
Density at $15^{\circ} \mathrm{C}$ & 0.8617 \\
Water and Sediment content Vol. $(\%)$ & 0.05 \\
Water content Vol. $(\%)$ & Traces \\
Reid Vapor Pressure (R.V.P.) $\left(\mathrm{Kg} / \mathrm{cm}^{2}\right)$ & 0.54 \\
\hline
\end{tabular}

*Iraqi ministry of oil/Midland refineries co./AL-Dura refinery.

$\mathrm{D}_{\mathrm{b}}=$ Light density for Chl-a extraction before adding $2 \mathrm{~N} \mathrm{HCl}$ at $(665 \mathrm{~nm})$.

$\mathrm{D}_{\mathrm{a}}=$ Light density for Chl-a extraction after adding $2 \mathrm{~N} \mathrm{HCl}$ at $(665 \mathrm{~nm})$.

$\mathrm{V}=$ solvent volume.

$\mathrm{L}=$ photocell (Cuvette) length (cm).

Doubling times $(\mathrm{G})$ was calculated from the formula proposed by Reynolds [25].

$$
\text { Doubling time }(\mathrm{G})=\ln 2 / \mu
$$

where, $\mu$ is the specific growth rate which was determined by the following equation [26].

$$
\mu=\ln \left(\mathrm{X}_{2} / \mathrm{X}_{1}\right) /\left(\mathrm{t}_{2}-\mathrm{t}_{1}\right)
$$

where, $\mathrm{X}_{1}$ and $\mathrm{X}_{2}$ Chlorophyll-a concentration at the beginning (day $\mathrm{t}_{1}$ ) and at the end (day $\mathrm{t}_{2}$ ) of the time interval under consideration, respectively.

\subsection{Statistics}

Growth data was subjected to standard one-way Analysis of Variance (ANOVA) according to [27]. All means were tested by the least-squares difference (LSD), where the difference of $p \leq 0.05$ was significant. Leastsquares linear regression analysis was applied to evaluate the relationship between the variables.

\section{Results}

The growth data indicated that both tested Cyanobacteria have slightly different behavior in response to crude oil depending on prepared concentrations and time of exposure, however, Microcystis flos-aquae appear to be sensitive than Nostoc carneum. Thus, the examined concentrations (10, 30, 50 and $70 \mathrm{mg} / \mathrm{l}$ ) caused gradual growth reduction of Microcystis flos-aquae, whereas the biomass of Nostoc carneumas were stimulated as long as exposure time were took place. Data presented in Figure 1 demonstrated that the growth of Microcystis flos-aquae expressed as chlorophyll-a content were negatively affected by crude oil ( $\mathrm{p} \leq 0.05$ ). The maximum pigment concentration was $0.108 \mu \mathrm{g} / \mathrm{ml}$ for control culture within exposure period, while with oil treated cells $(10,30,50$ and $70 \mathrm{mg} / \mathrm{l})$ these values gradually fell to $0.046,0.037,0.037$ and $0.022 \mu \mathrm{g} / \mathrm{ml}$ respectively after 96 hr of exposure.

Furthermore, growth rates of the same species decreased in oil treatments, the reduction was clear with all examined concentrations and for exposure period. Growth rates depending on chlorophyll-a measurement at 70 $\mathrm{mg} / \mathrm{l}$ reached to $(\mu=0.347 \pm 0.05)$. On contrary, an increasing in the doubling time of cells was detected with respect to examined concentrations as well as exposure duration. Doubling time value at $70 \mathrm{mg} / \mathrm{l}$ reached to ( $\mathrm{G}=$ $20.81 \pm 0.01$ ) (Table 2).

In the contrast, results showed variance response with Nostoc carneum on the same biomass indicator, which exposed a positive effects between examined concentrations $(10,30 \mathrm{mg} / \mathrm{l})$ as well as exposure time from hand and chlorophyll-a from other hand, while, a slightly toxic effects were observed with (50 and $70 \mathrm{mg} / \mathrm{l})$ in respect to control. Since the control values of chlorophyll-a observed as $0.29 \mu \mathrm{g} / \mathrm{ml}$, biomass calculations display continuous increasing in pigment levels during bioassay duration to $0.23,0.17$ for low oil concentrations and de- 
clined to $0.13,0.12 \mu \mathrm{g} / \mathrm{ml}$ with high concentrations respectively. Although, actual increasing were exhibited in the Cyanobacteria biomass, but it is still under control level for all examined concentrations in addition to total experiment time (Figure 2). Similarly, was observed with respect to growth rates and doubling time of cells within $96 \mathrm{hr}$. of exposure in all treatments. Calculated values at $70 \mathrm{mg} / \mathrm{l}$ reached to $(\mu=0.388 \pm 0.02),(\mathrm{G}=$ $17.86 \pm 0.05$ ) respectively (Table 2 ).

In the same context, reversed effect relationship was detected between growth rates and doubling time of cells, growth rates decreased with increasing of doubling time and vice versa when algae exposed to increasing oil concentrations as well as time of exposure. Although, the crude oil had a different effects in the algal biomass, The microscopical examination showed, algal cells aggregation in clusters containing oil drops between their cell comparing with control culture specially with Microcystis flos-aquae, whereas heterocysts separation from the filament were observed in case of Nostoc carneum (Figure 3).

One-way ANOVA statistical analysis indicated that the effect of crude oil on the algal growth was significant ( $\mathrm{p} \leq 0.05$ ). However, significant correlation (positive or negative) has been observed between growth rates and doubling time of cell in relation to the oil concentrations applied.

\section{Discussion}

The acute effect of the crude oil in present study was detected by using algal growth inhibition tests. Among various biological parameters indicated for the measurement of the oil toxicity, chlorophyll-a content was found to be more sensitive for assessing hydrocarbons toxicity than cell counting [28]. Petroleum compounds in general have been shown to either inhibit or stimulate algal growth, depending on the type and level of petroleum

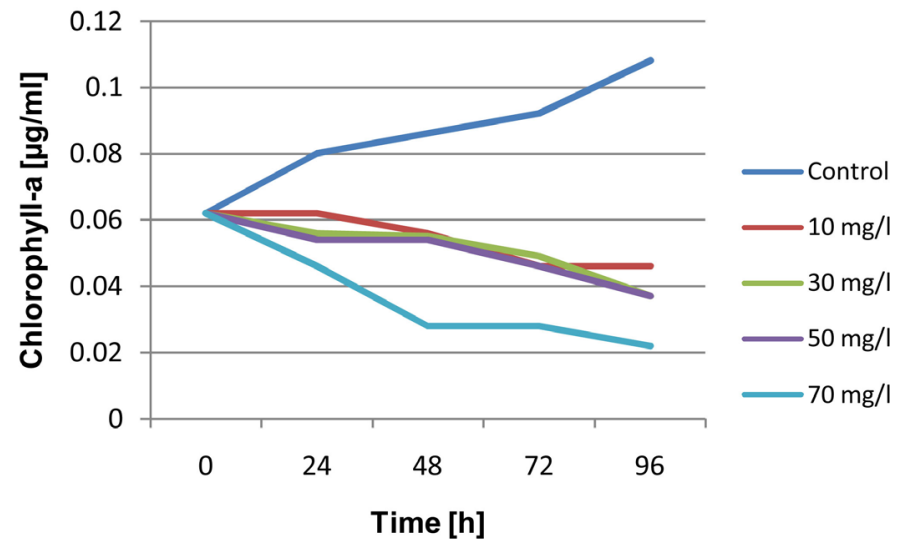

Figure 1. Growth curve of Microcystis flos-aquae when exposed to different concentrations of crude oil during $96 \mathrm{hr}$.

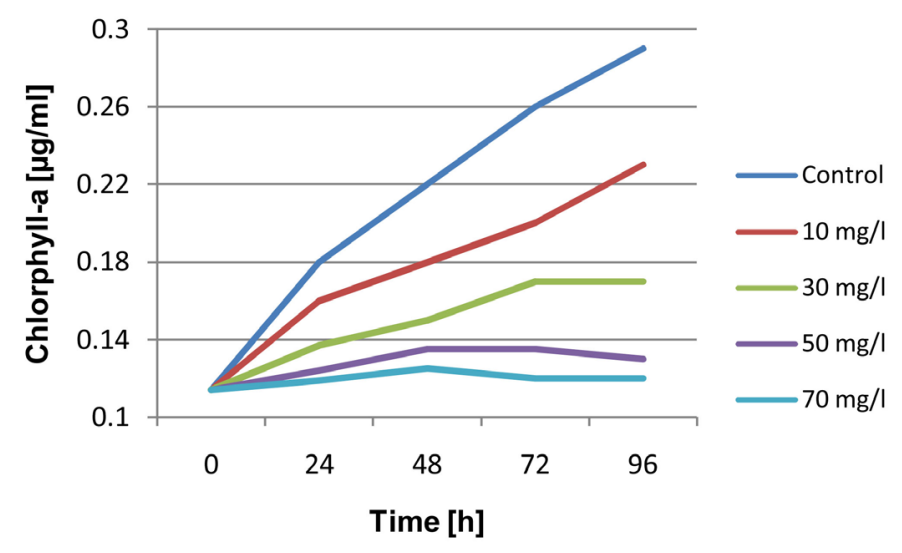

Figure 2. Growth curve of Nostoc carneum when exposed to different concentrations of crude oil during $96 \mathrm{hr}$. 
Table 2. Growth rates and doubling time of Mycrocystis flos-aquae and Nostoc carneum depending on chlorophyll-a concentration with respect to crude oil concentrations (mg/l).

\begin{tabular}{|c|c|c|c|c|}
\hline \multirow{2}{*}{$\begin{array}{c}\text { Concentrations } \\
\mathrm{mg} / \mathrm{l}\end{array}$} & \multicolumn{2}{|c|}{ Microcystis flos-aquae } & \multicolumn{2}{|c|}{ Nostoc carneum } \\
\hline & $\begin{array}{c}\text { Growth rate } \\
(\mu)\end{array}$ & $\begin{array}{l}\text { Doubling time } \\
\text { (G) hours }\end{array}$ & $\begin{array}{c}\text { Growth rate } \\
(\mu)\end{array}$ & $\begin{array}{l}\text { Doubling time } \\
\text { (G) hours }\end{array}$ \\
\hline Control & $0.597 \pm 0.001$ & $11.61 \pm 0.01$ & $0.576 \pm 0.002$ & $12.03 \pm 0.051$ \\
\hline 10 & $0.489 \pm 0.030$ & $14.17 \pm 0.02$ & $0.505 \pm 0.04$ & $13.72 \pm 0.003$ \\
\hline 30 & $0.456 \pm 0.001$ & $15.20 \pm 0.03$ & $0.455 \pm 0.002$ & $15.23 \pm 0.01$ \\
\hline 50 & $0.438 \pm 0.001$ & $15.82 \pm 0.04$ & $0.408 \pm 0.03$ & $16.98 \pm 0.009$ \\
\hline 70 & $0.347 \pm 0.05$ & $19.97 \pm 0.05$ & $0.388 \pm 0.02$ & $17.86 \pm 0.05$ \\
\hline
\end{tabular}

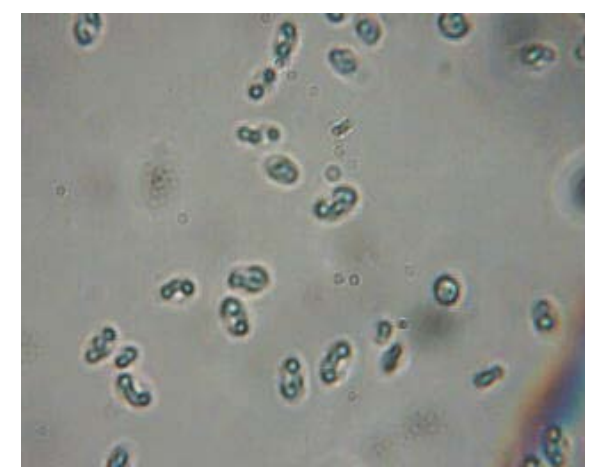

Microcystis flos-aquae in control culture

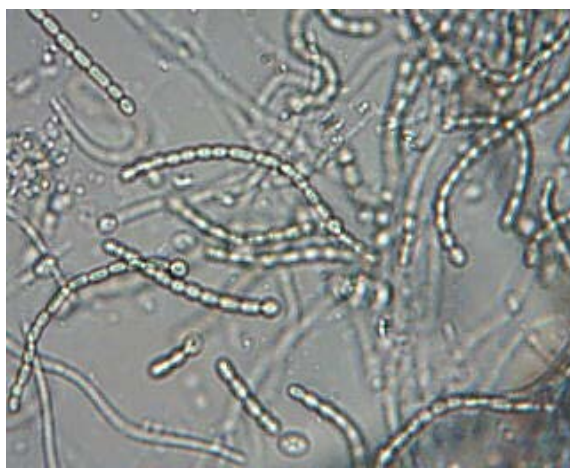

Nostoc carneum in control culture

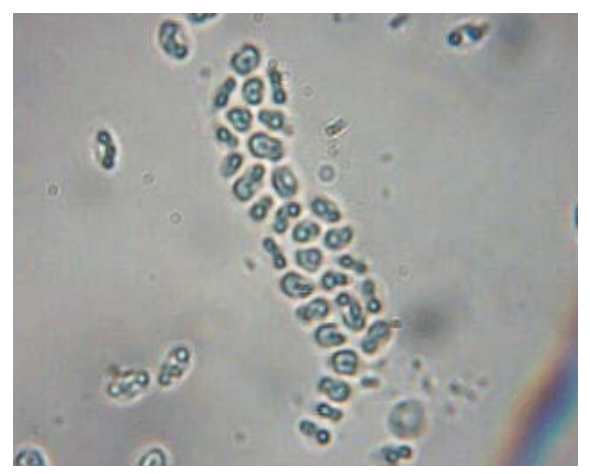

Microcystis flos-aquae in treated culture

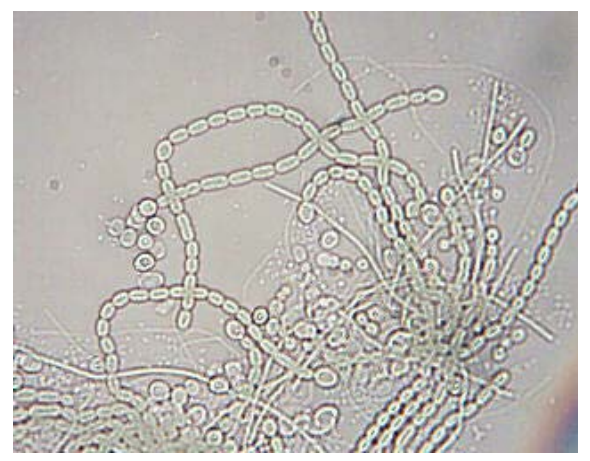

Nostoc carneum in treated culture

Figure 3. Morphological abnormality in Microcystis flos-aquae and Nostoc carneum after $96 \mathrm{hr}$ of contact to crude oil.

product and the algal species concerned [29] [30]. From this, The inhibitory effects of the crude oil on Microcystis flos-aquae proceeded with a much higher rate compared to the control resulting in death of the treated algae after addition tested concentrations, this is consistent with several studies [31]-[33] where they found that algal biomass measured by chlorophyll-a, photosynthesis and nitrogen fixation in some phytoplankton like Nitzschiapalea, Anabaena doliolum were severely inhibited by crude oil. Likewise, [34] observed decreasing in the number of cells and dry matter of the green alga Scenedesmus quadricauda when applied various concentrations of the crude oil and fuel oils. In the same subject, the clear reduction in the growth of Microcystis flos-aquae could be due to the cellular structure changes as a result to the toxic effects of the crude oil. This suggestion is agree with references of [35] and [36] who they found that the crude oil and diesel fuel affect membrane fluidity of many phytoplankton species though membrane disruption and alteration of plasma membrane fatty acid and 
sterol composition. Similarly findings, was observed with the microalgae Chamydomonas angulosa which revealed a significant total protein reduction when grown in batch culture with aqueous crude oil extract [37]. Moreover, The inhibition of DNA synthesis accompanied by slightly delayed cessation of RNA and protein synthesis as well as reducing in the Starch synthesis in chlorococcal alga Scenedesmus armatus were stated when exposed to various concentrations of dispersant (DP-105), a fuel oil and their mixtures [38]. The actual toxic effects of the oil concentrations on Microcystis agrees with the above suggestion and with results found by Al-Hassan et al. [39] who investigated the effect of oils on pure cultures of fresh water algae which showed that the growth of Scenedesmus quadricauda reduced by $10 \%$ lubricating oil and halted in the presence of diesel oil. Similar to that, Gamila and Ibrahim [40] stated that the Nitzschia linears revealed extended lag period of the growth with biomass less than control by $66 \%$ when treated with $0.1 \%$ crude oil.

On other hand, Present results indicate that the concentrations of crude oil have positive effects on the growth of Nostoc carneum. However, Dunstan et al. [41] have been reported that low concentrations of low molecular weight hydrocarbons stimulated the growth of some microalgae, while high concentrations were toxic. They attributed the stimulation of growth by low concentrations to the utilization of oil as a carbon source by the algal cells. Furthermore, the absence of the toxic influences of the crude oil on the growth of Nostocmight is due to its ability to accumulate the crude oil. This agrees with the explanation made by Petkov et al. [42], they clarified that microalgae Chlorella and Scenedesmus have been shown to assimilate petroleum hydrocarbons although the mechanism was not clearly known. They suggested that the stimulation of growth in the case of Chlorococcum sp.might be due to its ability to detoxify or metabolize some of the dissolved organic compounds present in the soil. Also, it was documented by Cerniglia [43] that marine Cyanobacteria have been shown to oxidize aromatic hydrocarbons under photoautotrophic growth conditions. Likewise, Ibrahim and Gamila [44] indicated that the treatment of algal culture with $0.1 \%$ crude oil led to prolongation the growth phases of the Nitzschia linearis and Scenedesmus obliquus as well as high algal biomass production. The late toxicity effects of the high tested concentrations on Nostoc carneum agree with Karydis [45] who stated that the inhibitory effects of $100 \mathrm{mg} / \mathrm{l}$ from crude oil became quite distinct from the $2^{\text {nd }}$ day after the addition of the oil on the growth of marine alga Skeletonemacostatum. However, problems in transportation of the hydrophobic compounds through cytoplasmic membrane may delay or prevent any potentially toxic impact on microalgae. With regard to the induced changes in the Cyanobacteria morphology, present observations is in good agreement with the references [46] [47], who observed that aqueous crude and fuel oil extracts has been shown to induced morphological abnormalities in the cell of Chlamydomonas angulosa and Scenedemus quadricauda in terms of increasing in cell size. Gaur and Singh [48] also reported that Assam crude oil had a serious effect on the heterocysts differentiation in Anabaena doliolum.

By means of statistical analysis, obtained data have highlighted significant growth response of the investigated cyanobacteria, which may be negative or positive. The growth rate of Micorcystis (as chlorophyll-a content) was negatively correlated with the studied concentrations of the crude oil, while it had a positive correlation in case of doubling time of cells. In contrast, in respect to growth rates and doubling time of Nostoc, these results are consistent with that documented by the references [49] who reported negative and positive correlation between growth of freshwater Cyanobacteria Oscillatoria agardhii, Anabaena spharica and marine microlaga Nannochloropsissalina respectively, and the concentrations of petroleum hydrocarbons. This reflects the potential efficiency of the tested cyanobacteria in the biomonitoring of crude oil over that for the natural community of freshwater phytoplankton.

\section{Conclusion}

Variance in the toxicity of the Iraqi crude oil according to the tested concentrations and time of exposure on the studied cyanobacteria, as well as mode of their sensitivity, suggesting that there sponses of these species to oil stress indicates their use for bio-monitoring purposes, basing on concept their own abilities to reflects information's on quality and quantitative aspects of the environment. Industries, pollution control boards and other related foundations should make use of algal criteria, besides physico-chemical parameters which have long been employed, more costly as well as unfriendly environmental side effects.

\section{Acknowledgements}

The authors express their sincere gratitude to the Iraq ministry of oil/Midland refineries co./AL-Dura refinery 
for providing the crude oil samples. The authors also want to thank the unknown referees for critically reviewing the manuscript and suggesting useful changes.

\section{References}

[1] Sullivan, M.J. and Currin, C.A. (2000) Community Structure and Functional Dynamics of Benthic Microalgae in Salt Marshes. In: Weinstein, M.P. and Kreeger, D.A, Eds., Concepts and Controversies in Tidal Marsh Ecology, Kluwer Academic Publishers, Dordrecht, 81-106. http://dx.doi.org/10.1007/0-306-47534-0_6

[2] Gouveia, L. (2011) Microalgae as a Feedstock for Biofuels. Springer Briefs in Microbiology. http://dx.doi.org/10.1007/978-3-642-17997-6

[3] NRC (1985) Oil in the Sea-Inputs, Fates and Effects (1985) National Research Council. National Academy Press, Washington DC, 43-88.

[4] Tarshis, I.B. and Rattner, B.A. (1982) Accumulation of C14-naphthalene in the Tissues of Redhead Ducks Fed Oil-Contaminated Crayfish. Archive of Environmental Contamination and Toxicology, 11, 155-159. http://dx.doi.org/10.1007/BF01054891

[5] Vaajasaari, K., Joutti, A., Schultz, E., Selonen, S. and Westerholm, H. (2002) Comparisons of Terrestrial and Aquatic Bioassays for Oil-Contaminated Soil Toxicity. Journal of Soils and Sediments, 2, 194-202. http://dx.doi.org/10.1007/BF02991039

[6] Booth, L., Heppelthwaite, V. and O’Halloran, K. (2005) Effects-Based Assays in the Earthworm Aporrectodea caliginosa: Their Utilisation for Evaluation of Contaminated Sites before and after Remediation. Journal of Soils and Sediments, 5, 87-94. http://dx.doi.org/10.1065/jss2004.10.116

[7] Grote, M., Schuurmann, G. and Altenburger, R. (2005) Modeling Photoinduced Algal Toxicity of Polycyclic Aromatic Hydrocarbons. Environmental Science and Technology, 39, 4141-4149. http://dx.doi.org/10.1021/es048310v

[8] Ostgaard, K. (1994) The Oil, the Water and the Phytoplankton. Advances in Limnology, No. 42, 167-193.

[9] Ito, T., Tanaka, M., Shinkawa, H., Nakada, T., Ano, Y., Kurano, N., Soga, T. and Tomita, M. (2013) Metabolic and Morphological Changes of an Oil Accumulating Trebuoxiophycean Alga in Nitrogen-Deficient Conditions. Metabolomics, 9, 178-187. http://dx.doi.org/10.1007/s11306-012-0463-z

[10] Gaur, J.P. and Kumar, H.D. (1981) Growth Response of Four Micro-algae to Three Crude Oils and a Furnace Oil. Environmental Pollution, 25, 77-85. http://dx.doi.org/10.1016/0143-1471(81)90116-1

[11] Greca, M.D., Monaco, P., Pollio, A. and Previtera, L. (1992) Structure Activity Relationships of Phenylpropanoids as Growth Inhibitors of the Green Alga Selenastrum capricornutum. Phytochemistery, 31, 4119-4123. http://dx.doi.org/10.1016/0031-9422(92)80425-E

[12] Chronopoulou, P.M., Fahy, A., Coulon, F., Passe, S., Goni-Urriza, M., Peperzak, L., Alvares, L.A., McKew, B.A., Lawson, T., Timmis, K.N., Duran, R., Underwood, G.J.C. and McGenity, T.J. (2013) Impact of a Simulated Oil Spill on Benthic Phototrophs and Nitrogen-Fixing Bacteria in Mudflat Mesocosms . Environmental Microbiology, 15, 242252. http://dx.doi.org/10.1111/j.1462-2920.2012.02864.x

[13] Mohammady, N.G., Chen, Y. C., El-Mahdy, A.A. and Mohammad, R.F. (2005) Physiological Responses of the Eustigmatophycean Nannochloropsis salina to Aqueous Diesel Fuel Pollution. Oceanologia, 47, 75-92.

[14] Prince, R.C. (2010) Eukaryotic Hydrocarbon Degraders. In: Timmis, K.N., McGenity, T.J., van der Meer, J.R. and Lorenzo, V., Eds., Handbook of Hydrocarbon and Lipid Microbiology, Springer, Berlin, 2065-2078. http://dx.doi.org/10.1007/978-3-540-77587-4 150

[15] Duran, R. and Goni-Urriza, M.S. (2010) Impact of Pollution on Microbial Mats. In: Timmis, K.N., McGenity, T.J., van der Meer, J.R. and Lorenzo, V., Eds., Handbook of Hydrocarbon and Lipid Microbiology, Springer, Berlin, 2339-2348. http://dx.doi.org/10.1007/978-3-540-77587-4 170

[16] McGenity, T.J., Folwell, B.D., Mckew, B.A. and Sanni, G.O. (2012) Marine Crude-Oil Biodegradation: A Central Role for Interspecies Interactions. Aquatic Biosystems, 8, 10. http://dx.doi.org/10.1186/2046-9063-8-10

[17] Volkering, F., Breure, A.M., Sterkenburg, A. and van Andel, J.G. (1992) Microbial Degradation of Polycyclic Aromatic Hydrocarbons: Effect of Substrate Availability on Bacterial Growth Kinetics. Applied Microbiology and Biotechnology, 36, 548-552. http://dx.doi.org/10.1007/BF00170201

[18] Wodzinski, R.S. and Coyle, J.E. (1974) Physical State of Phenanthrene for Utilization by Bacteria. Applied and Environmental Microbiology, 27, 1081-1084. http://aem.asm.org/content/27/6/1081

[19] Sikkema, J., de Bont, J.A. and Poolman, B. (1995) Mechanisms of Membrane Toxicity of Hydrocarbons. Microbiology and Molecular Biology Reviews, 59, 201-222. http://mmbr.asm.org/content/59/2/201

[20] Wang, Q., Zhang, S., Li, Y. and Klassen, W. (2011) Potential Approaches to Improving Biodegradation of Hydrocarbons for Bioremediation of Crude Oil Pollution. Journal of Environmental Protection, 2, 47-55. 
http://dx.doi.org/10.4236/jep.2011.21005

[21] Chu, S.P. (1942) The Influence of the Mineral Composition of the Medium on the Growth of Planktonic Algae: Part I. Methods and Culture Media. The Journal of Ecology, 30, 284-325. http://links.jstor.org/sici?sici=0022-0477\%28194208\%2930\%3A2\%3C284\%3ATIOTMC\%3E2.0.CO\%3B2-4

[22] Patterson, G. (1983) Effect of Heavy Metals on Fresh Water Chlorophyta. Ph.D. Thesis, Durham University, England.

[23] Karydis, M. (1979) Short Term Effects of Hydrocarbons on the Photosynthesis and Respiration of Some Phytoplankton Species. Botanica Marina, 22, 281-286. http://dx.doi.org/10.1515/botm.1979.22.5.281

[24] Vollenweider, R.A. (1974) A Manual on Methods for Measuring Primary Productivity in Aquatic Environments. 2nd Edition, IBP Handbook, No. 12, Blackwell Scientific Publication, Oxford.

[25] Reynolds, C.S. (1984) The Ecology of Freshwater Phytoplankton. Cambridge University Press, Cambridge.

[26] APHA, WWA and WEF (2005) Standard Methods for Examination of Water and Waste Water. 21st Edition, American Public Health Association, Washington DC.

[27] Agarwal, B.L. (1988) Basic Statistics. Wiley Eastern Ltd., New Delhi, 748.

[28] Oberholster, P.J., Blaise, C. and Botha, A.M. (2010) Phytobenthos and Phytoplankton Community Changes upon Exposure to Sunflower Oil Spill in a South African Protected Freshwater Wetland. Ecotoxicology, 19, 1426-1439. http://dx.doi.org/10.1007/s10646-010-0528-6

[29] Margesin, R., Labbe, D., Schinner, F., Greer, C.W. and Whyte, L.G. (2003) Characterization of Hydrocarbon-Degrading Microbial Populations in Contaminated and Pristine Alpine Soils. Applied and Environmental Microbiology, 69, 30853092. http://dx.doi.org/10.1128/AEM.69.6.3085-3092.2003

[30] De Oteyza, T.G., Grimalt, J.O., Diestra, E., Sole, T. and Esteve, I. (2004) Changes in the Composition of the Polar and Apolar Crude Oil Fractions under the Action of Microcoleus Consortia. Applied Microbiology and Biotechnology, 66, 226-232. http://dx.doi.org/10.1007/s00253-004-1694-3

[31] Kusk, K.O. (1978) Effects of Crude Oil and Aromatic Hydrocarbons on the Photosynthesis of the Diatom Nitzschia palea. Physiologia Plantarum, 43, 1-6. http://dx.doi.org/10.1111/j.1399-3054.1978.tb01558.x

[32] Miller, M.C., Alexander, V. and Barsdate, R.J. (1978) The Effects of Oil Spills on Phytoplankton in an Arctic Lake and Ponds. Arctic, 31, 192-218.

[33] Miller, M.C., Hater, G.R. and Vestal, J.R. (1978) Effect of Prudhoe Crude Oil on Carbon Assimilation by Planktonic Algae in an Arctic Pond. In: Adrino, D.C. and Brisbin, I.L., Eds., Environmental Chemistry and Cycling Processes, Conference 760429, US Department of Energy, Washington DC, 833-850.

[34] Tukaj, Z. (1987) The Effects of Crude and Fuel Oils on the Growth, Chlorophyll ' $a$ ' Content and Dry Matter Production of a Green Alga Scenedesmus Quadricauda (Turp.) Bréb. Environmental Pollution, 47, 9-24. http://dx.doi.org/10.1016/0269-7491(87)90118-7

[35] Van Putte, R.D. and Patterson, C.O. (1995) Isolation and Purification of Plasma Membranes form Three Species of Marine Microalgae. Proceeding of Phycolgical Society of America, Breckenridge, 31, 8.

[36] Nechev, J.T., Khotimchenko, S.V., Ivanova, A.P., Stefanov, K.L., Dimitrova-Konaklieva, S.D., Andreev, S. and Popov, S.S. (2002) Effect of Diesel Fuel Pollution on the Lipid Composition of Some Wide-Spread Black Sea Algae and Invertebrates. Zeitschrift für Naturforschung. C, 57, 339-343.

[37] Soto, C., Hellebust, J.A. and Hutchinson, T.C. (1977) Effect of Naphthalene and Aqueous Crude Oil Extracts on the Green Flagellate Chlamydomonas angulosa. III. Changes in Cellular Composition. Canadian Journal of Botany, 55, 2765-2777. http://dx.doi.org/10.1139/b77-315

[38] Zachleder, V. and Šetlik, I. (1982) Effect of Irradiance on the Course of RNA Synthesis in the Cell Cycle of Scenedesmus quadricauda. Biologia Plantarum, 24, 341-353. http://dx.doi.org/10.1007/BF02909100

[39] Al Hasan, R.H., Sorkhoh, N.A., Al-Bader, D. and Radwan, S.S. (1994) Utilization of Hydrocarbons by Cyanobacteria from Microbial Mats on Oily Coasts of the Gulf. Applied Microbiology and Biotechnology, 41, 615-619. http://dx.doi.org/10.1007/BF00178499

[40] Gamila, H.A. and Ibrahim, B.M. (2004) Algal Bioassay for Evaluating the Role of Algae in Bioremediation of Crude Oil: I. Isolated Strains. Bulletin of Environmental Contamination and Toxicology, 73, 883-889. http://dx.doi.org/10.1007/s00128-004-0509-7

[41] Dunstan, W.M., Atkinson, L.P. and Natoli, J. (1975) Stimulation and Inhibition of Phytoplankton Growth by Low Molecular Weight Hydrocarbons. Marine Biology, 31, 305-310. http://dx.doi.org/10.1007/BF00392087

[42] Petkov, G.D., Furnadzieva, S.D. and Popov, S.S. (1992) Petrol-Induced Changes in the Lipid and Sterol Composition of Three Microalgae. Phytochemistry, 31, 1165-1166. http://dx.doi.org/10.1016/0031-9422(92)80253-B

[43] Cerniglia, C.E. (1984) Microbial Metabolism of Polycyclic Aromatic Hydrocarbons. Advances in Applied Microbiology, 30, 31-71. http://dx.doi.org/10.1016/S0065-2164(08)70052-2 
[44] Ibrahim, M.B.M. and Gamila, H.A. (2004) Algal Bioassay for Evaluating the Role of Algae in Bioremediation of Crude Oil: II. Freshwater Phytoplankton Assemblages. Bulletin of Environmental Contamination and Toxicology, 73, 971-978. http://dx.doi.org/10.1007/s00128-004-0521-y

[45] Karydis, M. (1981) The Toxicity of Crude Oil for the Marine Alga Skeletonema costatum (Greville) Cleve in Relation to Nutrient Limitation. Hydrobiologia, 85, 137-143. http://dx.doi.org/10.1007/BF00006623

[46] Soto, C., Hutchinson, T.C., Hellebust, J.A. and Sheath, R.G. (1979) The Effect of Crude Oil on the Morphology of the Green Flagellate Chlamydomonas angulosa. Canadian Journal of Botany, 57, 2717-2728. http://dx.doi.org/10.1139/b79-322

[47] Tukaj, Z., Kentzer, T. and Bohdanowicz, J. (1984) The Influence of Fuel Oil on the Growth and Cell Morphology of Scenedesmus quadricauda (Turp.) Breb. Proceeding of 14 Conference of Baltic Oceanographers, 2, 830-844.

[48] Gaur, J.P. and Singh, A.K. (1990) Growth, Photosynthesis and Nitrogen Fixation of Anabaena doliolum Exposed to Assam Crude Extract. Bulletin of Environmental Contamination and Toxicology, 44, 494-500. http://dx.doi.org/10.1007/BF01701235

[49] Gamila, H.A., Ibrahim, M.B.M. and Abd El-Gafar, H.H. (2003) The Role of Cyanobacterial Isolated Strains in the Biodegradation of Crude Oil. International Journal of Environmental Studies, 60, 435-444. http://dx.doi.org/10.1080/0020723032000050367 